\title{
Local Wisdom in Japanese Community through a Myth of Yamagami in Novel Kamusari Na Na Nichijou
}

\author{
Wawat Rahwati \\ \{wawat.rahwati@yahoo.com\} \\ Universitas Nasional, Indonesia
}

\begin{abstract}
This paper discusses the local wisdom in Japanese society through a myth of Yamagami in Japanese novel namely Kamusari Na Na Nichijou written by Miura Shion. The story tells about Yuki Hirano a young boy from Yokohama, one of the major cities in Japan who decided to be a forest worker and live in a countryside of Kamusari Mountain for one year. During staying in that village, he was extremely surprised by the tradition of that community. The people in the village believe a myth about the existence of a Goddess of Mountain (Yamagami) is called Ooyamazomi who controls that place. By using ecofeminism theory, this paper aim to show that the local wisdom of community in Kamusari village related closely to the myth of Yamagami which is considered by cultural ecofeminists as the 'Goddess Earth Mother' which gives life through its natural resources. For expressing their feeling of reciprocity and gratitude to Yamagami, they offering dances, songs, and a festival of Ooyamazomi which all refer to the spirit activities of the cultural ecofeminism.
\end{abstract}

Keywords: Kamusari Na Na Nichijou, Local Wisdom, Cultural Ecofeminism, Yamagami

\section{Introduction}

$\mathrm{Na} \mathrm{Na} \mathrm{Kamusari} \mathrm{Nichijou} \mathrm{(The} \mathrm{Easy} \mathrm{Life} \mathrm{in} \mathrm{Kamusari)} \mathrm{is} \mathrm{one} \mathrm{of} \mathrm{Japanese} \mathrm{novel} \mathrm{written}$ by Miura Shion which is classified as a Seishun shousetsu (teen novel). This novel was published in 2012 by Tokuma Shoten publishing and adapted into comedy genre film which entitled Wood Job in 2014. This novel tells the experience of main character named Yuki Hirano, a student from Yokohama, one of big city in Japan who taking a part for internship training as a forest worker for a year in Nakamura Ringyo which located at Kamusari mountain area. Since this novel has been published, there are many responses about this novel, not only came from literary review but also from other researcher who working in different field with different perspective. One of them is Kawasaki Akie, a professor from Kyusu University who responded to this novel by relating it to labor issues in forestry sector and high rate of elderly problem which is being faced by Japan nowadays.

Kawasaki [1] stated that the film Wood Job which is based on novel $\mathrm{Na} \mathrm{Na} \mathrm{Kamusari}$ Nichijou was launched in 2014 and that novel talks about daily life in a village of Kamusari mountain with many surprising things that never been imagined before. This story has been portrayed with stunning views through of a young man's view named Yuki Hirano who came from a big city and moved to this place for internship as forest worker. Kawasaki said that this novel is so impressive and gives new ideas. As a result of this works, there are so many people who interested in forestry sector and this issue has become a big theme among researchers of Forestry Journal. 
Even as a teen novel, in this novel there are important issues which portrayed through perspective of Yuki Hirano as a main character. The issues seem related to myth of Yamagami, as a collective belief in local community of Kamusari village. The people of Kamusari believe that Yamagami is a goddess who dwelled and guard that place. So therefore, people who live in that village are consider that the Kamusari Mountain as a sacred mountain. The sacredness of this mountain is represented by the local community who still strongly believe and hold on tight this myth which confirmed about its sacredness. Regarding of myth, Doty [2] quoted Alan Dundes by saying that the term of myth was taken from the Greek language refers to the folklore which tell about story of the past which related to the creation of the universe and the gods that are believed exist by people in their place. The strong belief of the Kamusari village community towards that myth indirectly emerged some of local wisdom as rules in the Kamusari community related to their interactions with nature that are considered sacred.

According to local wisdom, Maharddhika [3] explained the definition of local wisdom by borrowing Naritoom's opinion which states that "Local wisdom is the knowledge that was discovered or acquired by local people through the accumulation of experiences in trials and integrated with the understanding of surrounding nature and culture". In other word, that local wisdom refers to everything related to the knowledge by the local community through various accumulated experiences that give understanding about the nature conditions and culture environment, as well as experiences related to myth prevailing in a society. Through this novel, I want to know how the myth of Yamagami (the goddess of mountain) emerged some of local wisdom in Japanese community, in case of people who live in the village of Kamusari which portrayed through the characters and story setting in the novel.

\section{Methodology}

This study analysis a Japanese novel titled Kamusari Na Na Nichijo [4] which published in 2012 by Tokuma Bunsho, Tokyo is aiming to find how the myth of Yamagami as a goddess of Kamusari Mountain emerged some of local wisdom in community of Kamusari village. I use a method of close reading to analysis the text more deeply to find what kind of discourse is contained in it. According to Eagleton [5], close reading is one of method which in fact is to do more than insist on due attentiveness to the text. It inescapably an attention to this rather than to something else; to the words on the page rather to the contexts which are produced and surround them.

After I found the discourses that showed the forms of local wisdom seen in the novel $\mathrm{Na}$ $\mathrm{Na}$ Nichijou Kamusari, I continue to analysis how those of local wisdom relate to myth of Yamagami by using cultural ecofeminism as a basic theory. I use this because the theory is based on the existence of a view which said that ecofeminists are a movement of thought that emphasizes the relationship between women's relations with nature. Ehara and Kanai in book entitled Ekofeminizumu [6] quoted Griffin's statement that between women and nature have a special spiritual relationship. The spiritual dimension in the view of cultural ecofeminists is seen as "A holistic vision of Earth of the Earth has been present in many communities, cultures, and civilization throughout history, and has often been allied with beliefs in the Earth Mother, where the earth was seen as a sacred, nurturing being" [7]. In other words, the views of cultural ecofeminists often attribute to nature as a sacred life-giving 'Mother Earth', the creator of everything that exists and in general such views can be found in various communities, cultures, and civilizations. Cultural ecofeminists assumed that nature as a Mother Earth which known as 
'Gaia', a classic Greek word that refers to the name of God which is also referred to as 'Goddess Mother Earth'.

Related to its activities, this cultural ecofeminist group is strongly influenced by earthbased spiritual elements, including worship of the goddesses, healing performed by female shamans, and worship of women's bodies. These various forms of activities ultimately lead to the main goal of cultural ecofeminism, namely as an alternative in healing and improving through woman culture as an effort to overcome environmental problems and other social problems. As common with other feminists, the concept of women's culture in the view of cultural feminists as stated by King [8] is a culture that places the defense, worship and value of femininity and nature which indirectly undermines patriarchal culture which tends dualism, hierarchy, and domination. Cultural ecofeminists build a concept of thinking about the relationship between women and nature through various forms of activities that can show the identity of women and nature, such as songs, performances, myths, ceremonies, shaman women's associations or also known as shamans. In many of communities, activities that are associated with worship of nature can still be found and are still maintained today through folklore stories and myths that are believed collectively by the local communities.

Regarding the concept of myth, Bascom [9] states that Myth is prose narrative which in the society in which they are told, are considered to be truthful account of what happened in the remote past. They are accepted on faith they are taught to be believed. Myth is the embodiment of dogma, they are usually sacred, and they are often associated with theology and ritual. Observing to Bascom's statement, I consider that the myth can be interpreted as a narrative process that is told collectively in a society about something that has happened in the past which is believed and accepted by its truth. Myth is also a manifestation of a dogma that is considered sacred and often associated with ritual. In a community, some rituals are often associated with how the people are dealings with nature and their environment that being emerged some of local wisdom forms which are obtained through various accumulations of their experiences related to the condition of culture and environment.

\section{Findings and Discussion}

\subsection{Findings}

Through the analysis of novel Kamusari Na Na Kamusari Nichijou, I found some of local wisdom forms which related to the existence of myth that are still believed by community in Kamusari village. Base on Yuki's view and narration, the local people in Kamusari still strongly believe in myth of Yamagami (a Goddess of Mountain) which are seen in this novel. They believe that Oyamazomi as a name of Mountain Goddess which reside in Kamusari Mountain. According to that myth, there are several local rules that must be followed by people who lived in Kamusari which indicated to their local wisdom. One of those is they must respect the forest of Kamusari with all living things when they entered to the forest. Therefore, they do not kill animal except the poisonous snake like Mamushi and they avoid to kill nonpoisonous snakes which assumed as a messenger of goddess. The people in Kamusari village live in harmony and modestly. Even they have rich natural resources such as good quality woods, they don't use all that woods excessively. They just cutting down some of big trees and before then, they do some ceremonies which presented to the Yamagami Goddess for showing their grateful expression. All those rules as local wisdom related to the myth of Ooyamazomi as a goddess of Kamusari 
Mountain which believed by people who live in Kamusari. For expressing their gratitude to the goddess of mountain, they arrange the huge festival known as Ooyamazomi matsuri (the festival of Ooyamazumi) which is held in once every 48 years. In that festival, they interact with Ooyamazumi as a goddess of mountain through the dancing and singing. According to the concept of cultural ecofeminism, Ooyaazomi represent of 'Goddess Mother Earth' which refers to relationship between women and nature. based on the analysis by using this theory, I assumed that the myth of Yamagami which appeared in novel of Kamusari Nana Nichijou represents some of rules of local wisdom which emphasized the relation between women and nature has spirit connection, as a main concept in cultural ecofeminism.

\subsection{Discussion}

The discussion of novel Na Na Kamusari Nichijou will be carryed out by doing analysis the structures of novel such as characters and setting of stories to find some of local wisdom forms and its correlation with the existence of myth which are still believed by community who live in Kamusari village. The discourse related to local wisdom forms can be showed through exploring dominant characters which appear in the novel by illustrating the characters and their thoughts. The structures of this novel are built by a story from based on the experience of Hirano Yuki, a main character and next will be called just Yuki. Beside as main character, Yuki also acts as a narrator which is portrayed as a student who lives in Yokohama city and has just graduated from High School.

At the beginning of the story, Yuki's character is depicted as an 18-year-old lazy student. He was so relaxed even though he failed the university entrance exam [4]. The failure in the test for Yuki is not something to be regretted because he thinks that he can take the exam again for next year. So that is why Reina, as his girlfriend couldn't stand it and choose to break up with Yuki. However, along with the development of story, Yuki's attitude has changed since he has attended to forest worker training program for one month. At the first time, Yuki was reluctant to take part in this program, but due to the insistence of his parents and teacher, finally he decided to leave Yokohama and make a long journey to an isolated place is called Kamusari village for attending internship program. Kamusari is a totally isolated place, which is the cell phone signal cannot reach at there. Yuki almost gave up and intended to quit from this program by leaving this place quietly, but since he met with Naoki, a young woman who lived in that place, he decided to continue this training and show to her that he is not a spoiled young man as she imagined.

After he was completing one month of training, Yuki was assigned to apprentice as a forest worker for one year at the Nakamura Ringyou company, a timber company which located at a village in foot of Kamusari mountain. During the internship, he stayed at the home of Yoki Iida, a senior forest worker and also as a mentor for Yuki during his internship. The village where is Yuki working is a quiet and isolated place. There is not easy to get some food and daily necessities, as well as limited transportation and communication facilities.

In this novel, there are some of issues that are portrayed through Yuki Hirano's perspective as a main character. The social setting of this story is portraying about local people who live in Kamusari village peacefully. The depicting of peaceful living more further strengthened by the word $\mathrm{Na} \mathrm{Na}$ which is a dialect expression that commonly used by local people which means "go slowly", "just relax" or refers to the broad meaning of "nodokade sugoshiyasuku hiyori desu $n e$ " [4] which means "peaceful, easy, and ideal". People who lived in Kamusari seem like to use a lot of dialect word na na in daily life because it is related to their activities as what Yuki said in the following quote below. 
The word nana is important for people who lived in Kamusari because it related to their work in a forest to cutting down trees for a long time ago. They finished their activities and go home in the afternoon. In this village because there is no entertainment place in the evening, they usually go to sleep early. They eat as well as sleep well and, in the morning, they slowly go to the mountain for their job [4].

Base on Yuki's narration, the village where Yuki has been staying is very unique, located at Kamusari region and surrounded by mountains. While he is staying in this village, he realized that the local people in Kamusari still strongly believe in myth of Yamagami (a goddess of Mountain) which are seen in this novel. They believe that Oyamazomi as a name of Goddess of mountain which reside in Kamusari mountain as what Sabura and Iwao as local people said to Yuki about this myth.

Yuki asked to them "Can you tell me who is Oyamazomisan?" Iwao and Saburo looking at to each other. They seem confused to find the way how to answer my question, and then finally Seiichi said to me that Ooyamazomi live in Kamusari Mountain. It is the name of Kamusari Mountain's goddess [4].

The local people still believe in Ooyamazomi as a goddess of Kamusari mountain and they assume that the Kamusari is sacred mountain. Regarding to the myth of Ooyamazomi and sacredness of Kamusari mountain, there are several local rules were being holding a tight by people who lived in Kamusari which indicated of their local wisdom. One of those rules is must respect the forest of Kamusari with all living things in there when they entered to the forest. People who working in the forest like Ida Yoki as a Yuki's mentor, Shigeru, and Iwao are believe that they prohibited to kill animal except the poisonous snake like Mamushi which is usually used for daily food. Except the Mamushi, they avoid to kill nonpoisonous snakes which assumed as a messenger of goddess [4]. According to this belief, Iwao explained that in the mountain we never know what will happen in there. All we can do just ask to the goddess for helping and guarding us stay safe while we are working in the forest. For this reason, we do not ever kill animal in this village uselessly [4].

Beside not killing the animal, people in Kamusari is depicted in this novel live in harmony with the nature and they never disturb each other. There is a statement in the novel which describe that "The living thing which lived in the mountain will never enter to the area which people lived. Mountain is mountain, and people is people. We are as a human never allow to disturb the mountain. If someone forget or reluctant to keep this rule, the goddess of Kamusari will be angry [4]. Through portraying of story setting, the living in Kamusari is so slowly and people live in modestly, even they have rich natural resources such as good quality woods which can be sold with a good price, but they don't use all that woods excessively. They only choose the big trees to be cut down and before then, they do some ceremonies which presented to the goddess for showing their grateful [4].

For local people in Kamusari, Ooyamazomi is believed as a goddess of Kamusari who became the guardian of their village and forest, the goddess who always give prosperity through the nature and safety life to the villager. Because of this reason, local people of Kamusari village arrange the huge festival known as Ooyamazomi matsuri (the festival of Ooyamazumi) which is held in once every 48 years for expressing their gratitude to the goddess of mountain. In this novel also illustrated that local people believe in the year of Ooyamazumi festival is going to hold, sometimes it will happen that the goddess of mountain invites a child to come to her place 
for playing. The local people often said that this happening known as Kamikakushi (神隠) which means spirited away by the goddess and to looking for the missing child caused by this case, they need someone as a mediator who can connect and communicate to the goddess like Shige is one of women character in this novel who has ability to connect to goddess's world [4]. In Japanese society, there is a assumption that women can connect to the supernatural world which they called as a miko or female shaman. This assumption refers to Yanagita's statement [10] that in the past, one of the main tasks of women was to carried out spiritual activities, such as worship and recitation of prayer for the gods. In cultural ecofeminism theory, the shaman's practice is one of main activity for cultural ecofeminist group which strongly influenced by earth-based spiritual elements, including worship of the goddesses such as worship to Ooyamazomi, a goddess of Kamusari mountain and the healing performed by female shamans.

In the festival of Ooyamazumi which is described in this novel, they interact with Ooyamazumi as a Yamagami through the dancing and singing. In the midnight before the day of the festival, the men in the community of Kamusari go to the mountain and worship to the goddess of Ooyamazomi. According to the concept of cultural ecofeminism, Ooyaazomi represent of 'Goddess Mother Earth' which refers to relationship between women and nature. In local community like Kamusari villager, some activities which related to the worship of the goddesses can still be found and are still maintained until nowadays through folklore stories and myths which they are believed collectively by the local community.

\section{Conclusion}

In analyzing novel of Kamusari Nana Nichojou by using a theory of cultural ecofeminism found the result that the local wisdom which still holding in tight by the local people in Kamusari village related to the myth of Ooyamazomi, a goddess of Kamusari Mountain. This myth is considered by cultural ecofeminist group as the "Goddess Mother Earth" who become the guardian of their village and forest and who always gives life prosperity through the resource of nature. Therefore, as a feeling of reciprocity and gratitude to the goddess, the people are offering a huge festival to conduct worship, dances, and songs which all refer to the spiritual activities of cultural ecofeminism.

Regarding to the myth of Ooyamazomi and sacredness of Kamusari Mountain, there are several local rules were being holding a tight by people who lived in Kamusari which indicated of their local wisdom. There are several rules that must be followed by the people in Kamusari, for instance no kill animal except the poisonous snakes, live in harmony with the nature and do not disturb each other, and do not use nature resources excessively. All those rules as local wisdom emerged as a form of their belief to the myth of Ooyamazomi, a goddess of Kamusari Mountain. The myth of Yamagami which appeared in novel can be shown to a research hypothesis that the novel of Kamusari Nana Nichijou represents some of rules of local wisdom which emphasized the relation between women and nature has spirit connection, as a main concept in cultural ecofeminism.

\section{References}

[1] A. Kawaski, "Ringyou rodousha no ima: tokushuu no kaidai ni kaete. Mori Kagaku Nihon Shinrin Gakka," Japanese For. Soc., vol. 78, no. 2-4, 2016.

[2] W. G. Doty, Myth: A handbook. Greenwood Publishing Group, 2004.

[3] Y. Maharddhika, "Indonesia's Experience: Regarding Our Local Wisdom And Promoting 
Community's Roles For Facing The Disasters," Public Adm. Dep. Gadjah Mada Univ. Retrieved from http//www. google. com/url, 2007.

[4] Miura, Kamusari nana nichijou. Tokyo: Tokuma Shoten, 2012.

[5] T. Eagleton, Literary theory: An introduction. John Wiley \& Sons, 2011.

[6] Y. K. Ehara, Feminizume. Tokyo: Shinyosha, 1997.

[7] C. Cox, "Ecofeminism," in Inventing women: science, technology and gender, G. Kirkup and L.

S. Keller, Eds. United Kingdom: Polity Press, 1998, p. 291.

[8] Y. King, "Healing the wounds: Feminism, ecology, and nature/culture dualism," in Feminism and Philosophy, Routledge, 2018, pp. 353-373.

[9] A. Dundes, Sacred narrative: Readings in the theory of myth. Univ of California Press, 1984.

[10] K. Yanagita, Imo no chikara. Tokyo: Kakugawa Bunsho, 1973. 